Provided for non-commercial research and education use. Not for reproduction, distribution or commercial use.

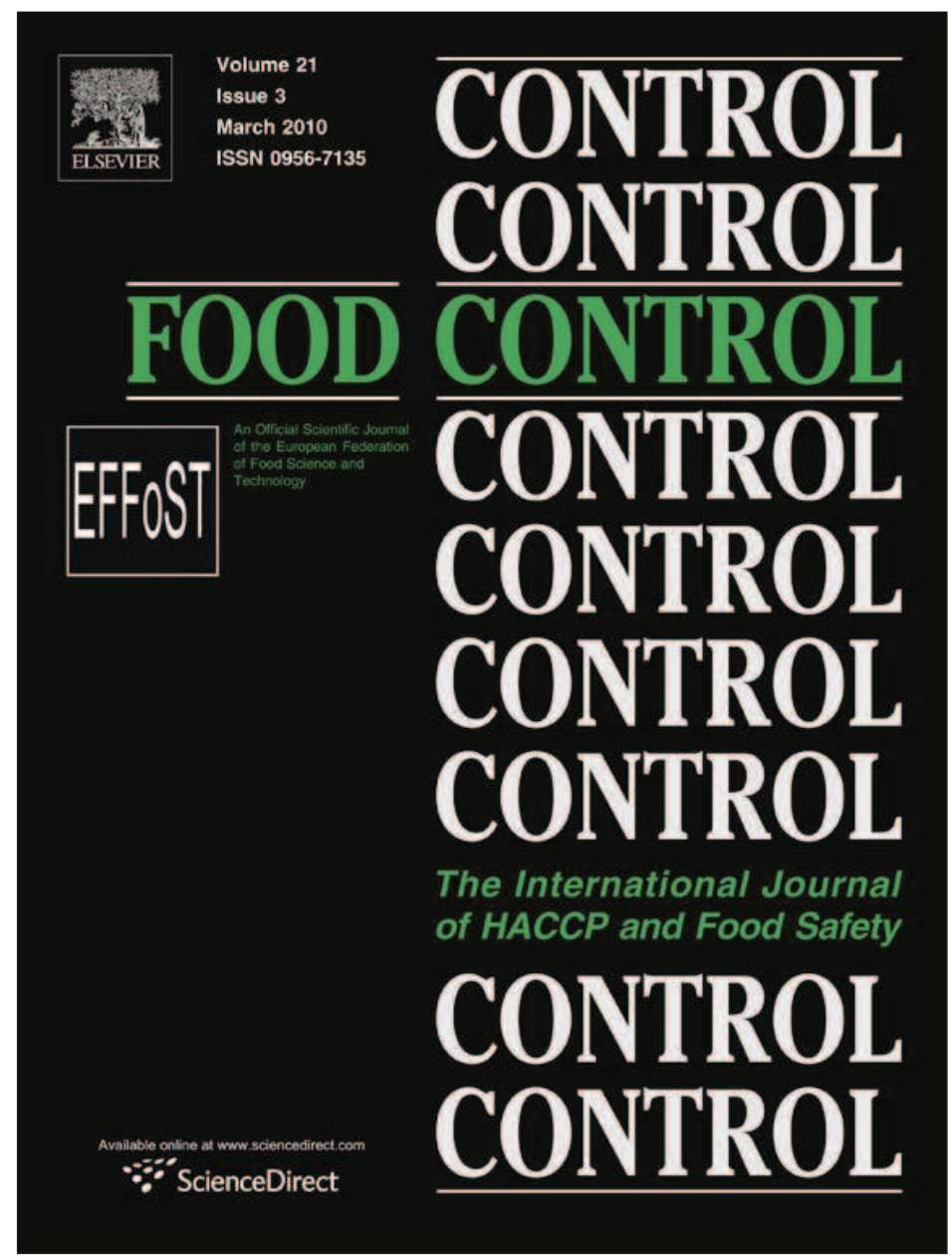

This article appeared in a journal published by Elsevier. The attached copy is furnished to the author for internal non-commercial research and education use, including for instruction at the authors institution and sharing with colleagues.

Other uses, including reproduction and distribution, or selling or licensing copies, or posting to personal, institutional or third party websites are prohibited.

In most cases authors are permitted to post their version of the article (e.g. in Word or Tex form) to their personal website or institutional repository. Authors requiring further information regarding Elsevier's archiving and manuscript policies are encouraged to visit:

http://www.elsevier.com/copyright 


\title{
Control of pathogenic and spoilage microorganisms from cheese surface by whey protein films containing malic acid, nisin and natamycin
}

\author{
Cristina M.B.S. Pintado ${ }^{\mathrm{a}, \mathrm{b}}$, Maria A.S.S. Ferreira ${ }^{\mathrm{b}}$, Isabel Sousa ${ }^{\mathrm{b}, *}$ \\ ${ }^{a}$ Escola Superior Agrária, Instituto Politécnico de Castelo Branco, Quinta da Senhora de Mércoles, 6001-909 Castelo Branco, Portugal \\ ${ }^{\mathrm{b}}$ Instituto Superior de Agronomia, Technical University of Lisbon, Tapada da Ajuda, 1349-017 Lisboa, Portugal
}

\section{A R T I C L E I N F O}

\section{Article history:}

Received 17 February 2009

Received in revised form 12 May 2009

Accepted 29 May 2009

\section{Keywords:}

Antimicrobial films

Cheese safety

Listeria monocytogenes

Rheology of films

\begin{abstract}
A B S T R A C T
The inhibitory effects of nisin, natamycin and malic acid, incorporated in whey protein films with $\mathrm{pH} 3$, were investigated alone or with addition of sucrose esters, Tween80 or EDTA. Water vapour permeability measurements and mechanical and rheological tests were also assessed. EDTA and Tween80 did not significantly $(P<0.05)$ influence the inhibitory activity of films against Pseudomonas aeruginosa and Yarrowia lipolytica in contrast with the improved effect against Listeria monocytogenes, Penicillium commune and Penicillium chrysogenum. Sucrose esters reduced significantly $(P<0.05)$ the inhibitory effect for $Y$. lipolytica and Penicillium spp. The present work provides an antimicrobial film formulation with potential to be a hurdle against spoilage and pathogenic microorganisms isolated from cheese surface.
\end{abstract}

(c) 2009 Elsevier Ltd. All rights reserved.

\section{Introduction}

Cheese is a ready-to-eat food easily contaminated on the surface by undesirable microorganisms. Some are spoilage microorganisms which may produce uncharacteristic visual appearance and diminish the commercial value of the cheeses, such as Yarrowia lipolytica, Pseudomonas aeruginosa and Penicillium spp. but others are pathogenic such as Listeria monocytogenes, which have been associated with foodborne listeriosis by consumption of cheese (McLauchlin, Mitchell, Smerdon, \& Jewell, 2004). The Gram-negative bacteria Pseudomanas spp. are the most important of the psychrotrophs that dominate the microflora of raw milk (Sorhaug \& Stepaniak, 1997). Strains of Ps. aeruginosa have been associated with undesirable browning reactions on cheese rind (Ogunnariwo \& Hamilton-Miller, 1975), and some are phatogenic. The Y. lipolytica yeast, frequently found in cheeses, was also reported to be associated with browning phenomenon (Carreira, Paloma, \& Loureiro, 1998). Penicillium is the genera of moulds most frequently isolated from naturally contaminated cheese rind samples and include mycotoxigenic strains. All these microorganisms comprise strains with psychrotrophic characteristics that could increase in number during cold storage (Sorhaug \& Stepaniak, 1997).

\footnotetext{
* Corresponding author. Address: Secção de Ciência e Tecnologia dos Alimentos, Departamento de Agro Indústrias e Agronomia Tropical, Instituto Superior de Agronomia, Technical University of Lisbon, Tapada da Ajuda, 1349-017 Lisboa, Portugal. Tel.: +351 213653 246; fax: +351 213653200 .

E-mail address: isabelsousa@isa.utl.pt (I. Sousa).
}

Most recently, the food industry showed an increasing interest in antimicrobial edible films to enhance food safety and product shelf life. Different matrix can be used to incorporate antimicrobial agents (Appendini \& Hotchkiss, 2002), including whey protein isolate (WPI). In general, the resistance to water vapour transmission of protein films is limited because they are highly polar polymers with a high level of hydrogen bonding and hydroxyl groups (Ko, Janes, Hettiarachchy, \& Johnson, 2001). Furthermore, in high humidity environments the water vapour barrier properties are subsequently reduced because of protein filmś susceptibility to moisture absorption and swelling. This attribute could be detrimental when foods coated by these films are submitted to high humidity storage conditions, increasing the diffusion coefficient of antimicrobial agents to the food from the film matrix. Therefore, the incorporation of agents such as fatty acid esters to decrease water vapour permeability (WVP) is necessary. Also, the type and concentration of plasticizer, such as glycerol and sorbitol, influences the ability of films to attract water.

Nisin is a hydrophobic and cationic polypeptide, a food-grade preservative that exhibits antimicrobial activity towards a wide range of Gram-positive bacteria but shows little or no activity against Gram-negative bacteria, yeasts, and moulds (DelvesBroughton, 2005). It has been observed that Gram-negative cells, normally insensitive to the action of nisin, can be sensitized by the addition of chelating agents, such as EDTA, which disrupt the integrity of the outer membrane and allow the bacteriocin to access the cytoplasmic membrane (Boziaris \& Adams, 1999; Stevens, Sheldon, Klapes, \& Klaenhammer, 1992). Sucrose esters of fatty acids and Tween80, used commonly as food emulsifiers, are non- 
ionic emulsifiers known to inhibit the growth of a wide range of microorganisms, primarily against Gram-positive bacteria and fungi, when used alone or in combination with an antimicrobial agent as nisin (Thomas, Davies, Delves-Broughton, \& Wimpenny, 1998) or organic acids (Monk, Beuchat, \& Hathcox, 1996). Natamycin is a polyene natural antimycotic with a wide range of antimicrobial spectrum against yeasts and moulds (Welscher, Napel, Balagué, Souza, Riezman, et al., 2008). Natamycin incorporating coat solutions are used by cheese industry but the commercial available products are in general based on polyvinyl acetate or polyvinyl alcohol, which food safety iniquity has been discussed (EFSA., 2005). This is of great concern because there are cheese consumers that appreciate cheese as a whole, consuming the inner and the rind of the cheeses.

The objectives of this work were to study how the incorporation of different emulsifier, plasticizer and chelator agents into WPIbased films with malic acid, nisin and natamycin interfere with the antimicrobial activity against $L$. monocytogenes, Ps. aeruginosa, Penicillium spp. and Y. lipolytica and the mechanical and WVP properties of the films.

\section{Materials and methods}

\subsection{Materials used to produce films and specifications}

Whey protein isolate (with a protein content of $92 \%$ minimum, dry basis) was kindly supplied by Carbery Food Ingredients, Ballineen, Co. Cork, Ireland. The sucrose esters of fatty acids were a gift from Mitsubishi-Kagaku Foods Corporation, Tokyo, Japan (Ryoto Sugar Ester S970 with 31-33\% sucrose monostearate and 20-22\% sucrose distearate, HLB-value 9) and from Sisterna B.V., BH Roosendaal, The Netherlands (SP30, nonionic emulsifier, sucrose distearate, HLB-value approx. 6, 30\% monoester content; and SP50, nonionic emulsifier, sucrose stearate, 50\% monoester content, HLB-value approx. 11). Nisin NP $\left(5 \times 10^{6} \mathrm{IU} / \mathrm{g}\right.$ potency), Nisaplin (minimum $10^{3} \mathrm{IU} / \mathrm{mg}$ of Nisin $\mathrm{A}$ and minimum $50 \% \mathrm{NaCl}$ ), and Natamax Salt were a gift from Danisco Beaminster Ltd., Beaminster, UK Glycerol and D-Sorbitol were purchased from Sigma Chemical Co., St. Louis (MO), USA; Hydrochloric acid from Riedel-de-Haën, Seelz, Germany; DL-Malic acid from BDH Chemicals Ltd.; EDTA from Aldrich, St. Louis (MO), USA; and Tween80 from Acroyali, Quingdao, China.

\subsection{Microbial cultures and media}

Twelve different microorganisms (Table 1 ) were used, which included six isolated from the rind of Castelo Branco Cheese, a semi- soft ripened ewe's cheese from the central part of Portugal (Pintado, Oliveira, Pampulha, \& Ferreira, 2005). The P2 and P6 strains of Ps. aeruginosa, and the moulds Penicillium chrysogenum and Penicillium commune, were isolated using selective agar media: Pseudomonas Aeromonas Selective Agar Base acc. to Kielwein (GSP Agar; Merck KGaA, Darmstadt, Germany) and Potato Dextrose Agar medium (PDA; from Oxoid, UK), respectively. Pseudomonas spp. strains were purified and identified to the species level using API $^{\circledR}$ 20NE (bioMérieux ${ }^{\circledR}$ SA, France). Ps. aeruginosa ATCC 15692 was kindly supplied by Instituto Superior Técnico, Technical University of Lisbon, and was used as reference strain. All the Pseudomonas strains used in this study were maintained at $4{ }^{\circ} \mathrm{C}$ on slants of TSYEGA medium $\left(1^{-1}\right)$ : 30 g Tryptone Soy Broth (Biokar Diagnostics, Beauvais, France), $6 \mathrm{~g}$ Yeast Extract (Oxoid), $10 \mathrm{~g}$ Glucose (COPAM, Portugal), and $18 \mathrm{~g}$ Agar (Dário Correia, Portugal), with the $\mathrm{pH}$ adjusted to 6.2 with $\mathrm{HCl}$. The $L$. monocytogenes strains were maintained at $-80^{\circ} \mathrm{C}$ in Trypticase ${ }^{\mathrm{TM}}$ Soy Broth (TSB; Becton, Dickinson and Company) containing 10\% (v/v) Glycerol, and subcultured twice in TSYEGB medium (containing the same components as TSYEGA, without Agar), at $37^{\circ} \mathrm{C}$ through $24 \mathrm{~h}$ and $18 \mathrm{~h}$ before use. Strains of $Y$. lipolytica were maintained at $4{ }^{\circ} \mathrm{C}$ on slants of GYPA medium which comprised $5.0 \mathrm{~g} \mathrm{l}^{-1}$ Peptone (Oxoid), $5.0 \mathrm{~g} \mathrm{l}^{-1}$ Yeast Extract (Oxoid), $2.0 \mathrm{~g} \mathrm{l}^{-1}$ Glucose (COPAM), and $20.0 \mathrm{~g} \mathrm{l}^{-1}$ Agar (Dário Correia), with the $\mathrm{pH}$ adjusted to 6.2 with $\mathrm{HCl}$. Ps. aeruginosa and $Y$. lipolytica strains were selected after assessing for the production of brown pigments on a Cheese-Tyrosine Agar medium (Carreira et al., 1998) containing $\left(1^{-1}\right)$ : $200 \mathrm{~g}$ soft cheese, $40 \mathrm{~g} \mathrm{NaCl}$ (Merck), $10 \mathrm{~g}$ L-tyrosine (Sigma), $12 \mathrm{~g}$ agar, and $\mathrm{pH}$ adjusted to 7.0. All six strains produced brown pigmentation in this medium. Strains of Penicillium spp. were isolated from rind of ripened cheeses and identified to the genera level using the following media: Czapek Yeast Autolysate Agar (CYA), Creatine Sucrose Agar (CREA), Yeast Extract Sucrose Agar (YES) and Blakeslee Malt Extract Autolysate Agar (MEA), as recommended by Samson and Frisvad (2005). The strains were then sent to Centraalbureau voor Schimmelcultures (CBS, Fungal Biodiversity Centre, The Netherlands) for further identification. They were identified as $P$. chrysogenum and $P$. commune. Penicillium roqueforti, PRB6 HYP5D, CHOOZIT, is a cheese culture used as reference, and was kindly supplied by Danisco (Copenhagen, Denmark).

\subsection{Preparation of film solutions and films}

Seven grams of whey protein isolate were completely dissolved in distilled water ( $100 \mathrm{ml}$ of total volume) by stirring for $15 \mathrm{~min}$. Glycerol or sorbitol $(1.5 \%, 2.25 \%$ and $3.0 \% \mathrm{w} / \mathrm{v})$ were then incorporated and stirred for a further $15 \mathrm{~min}$ followed by the addition of

Table 1

Identification and source of microorganisms used in this study.

\begin{tabular}{|c|c|}
\hline Microorganisms and references & Source of isolation \\
\hline L. monocytogenes NCTC 11994 & - \\
\hline L. monocytogenes CP6 & Rind of ewe's cheese \\
\hline L. monocytogenes M12 & Ewés cheese (Pintado et al., 2005) \\
\hline Ps. aeruginosa ATCC ${ }^{\text {b }} 15692$ & - \\
\hline Ps. aeruginosa P2 & Rind of ewe's cheese \\
\hline Ps. aeruginosa P6 & Ewés raw milk \\
\hline Y. lipolytica $\mathrm{CBS}^{\mathrm{C}} 6659$ & - \\
\hline Y. lipolytica ISA 1668 & Rind of ewe's cheese (Carreira et al., 1998) \\
\hline Y. lipolytica ISA 1708 & Rind of ewe's cheese (Carreira et al., 1998) \\
\hline P. roqueforti $\left(\mathrm{CHOOZIT}^{\mathrm{TM}} \text { PRB6 HYP5D }\right)^{\mathrm{d}}$ & - \\
\hline P. chrysogenum & Rind of ewe's cheese \\
\hline P. commune & Rind of ewe's cheese \\
\hline
\end{tabular}

\footnotetext{
a National collection of type cultures, London, United Kingdom.

b American type culture collection, Manassas (VA), USA.

c Centraalbureau voor Schimmelcultures, Delft, the Netherlands.

d Danisco, Copenhagen, Denmark.
} 
malic acid $(3.0 \% \mathrm{w} / \mathrm{v})$ and stirred a further $15 \mathrm{~min}$. After measuring the $\mathrm{pH}$ ( $\mathrm{pH}$ Meter M82, Radiometer, Copenhagen), the solutions were heated at $90^{\circ} \mathrm{C}$ for $30 \mathrm{~min}$ in a shaking water bath to form a film matrix by denaturation of protein. Once cooled at room temperature until approximately $50^{\circ} \mathrm{C}$, antimicrobial agents were incorporated into film solutions at final concentrations: Nisaplin ${ }^{\circledR}$ (50 IU nisin/ml), Natamax ${ }^{\circledR}$ Salt $(0.002 \mathrm{~g}$ of natamycin $/ \mathrm{ml}$ and $0.005 \mathrm{~g}$ of natamycin/ml), EDTA $(0.1 \%, \mathrm{w} / \mathrm{v})$, Tween $80(0.15 \%, \mathrm{w} /$ $\mathrm{v})$, sucrose distearate SP30 $(0.075 \%, \mathrm{w} / \mathrm{v})$, sucrose monostearateSP50 $(0.075 \%, \mathrm{w} / \mathrm{v})$ and sucrose monostearate S970 $(0.075 \%$, $\mathrm{w} / \mathrm{v}$ ). Film solutions were homogenised and $9 \mathrm{ml}$ were aseptically pipetted into $90 \mathrm{~mm}$ diameter disposable plates. After drying for $24-48 \mathrm{~h}$ at $23 \pm 2{ }^{\circ} \mathrm{C}$ and $50 \pm 5 \%$ relative humidity (RH), the films were peeled out from the plates and stored under these conditions until use. Films were cut into $70 \mathrm{~mm} \times 20 \mathrm{~mm}$ portions for mechanical measurements and aseptically cut into 6-mm-dia discs for inhibition assays.

\subsection{Antimicrobial diffusion-type assay}

The discs for the inhibition assay with antimicrobial agents were aseptically transferred to TSYEGA or GYPA plates, previously seeded with a swab of a $24 \mathrm{~h}$ culture of each organism given in Table 1, using the first medium for the bacteria and the second for the fungi. After an incubation of $24 \mathrm{~h}$ at $37^{\circ} \mathrm{C}$ for bacteria and 24 to $48 \mathrm{~h}$ at $25^{\circ} \mathrm{C}$ for yeasts and moulds, the width of the inhibition zone around each film disc was measured with a micrometer (Absolute Digimatic Calliper, Mitutoyo Ltd, Andover, UK), to the nearest $0.01 \mathrm{~mm}$, and the assay was done in three independent trials. Two different assays were done, the first for testing the interactions between nisin, malic acid and natamycin. The second assay was prepared aiming to test the incorporation of different agents to improve antimicrobial properties of the films.

\subsection{Film thickness}

Thickness of films was measured with a micrometer (Absolute Digimatic Calliper, Mitutoyo Ltd, Andover, UK; having a sensitivity of $0.01 \mathrm{~mm})$ around the film testing area $\left(70 \times 20 \mathrm{~mm}^{2}\right)$ at six random locations and averaged. The determinations were done before WVP and mechanical analysis assays.

\subsection{Water vapour permeability determination}

Water vapour permeability of films was measured using the ASTM Standard Method E96-95 (ASTM., 1995), known as the "cup method", modified by McHugh, Avena-Bustillos, and Krochta (1993) to be applied to edible films. Circular film specimens of $3.2 \mathrm{~cm}$ diameter were sealed with silicon onto the mouth of small circular test glass cups with $5 \mathrm{ml}$ of distilled water and placed inside an excicator with silica that was placed under the perforated platform where cups were placed. A fan set to generate an air flow of $180 \mathrm{rpm}$ was placed above the cups to maintain moisture conditions at the film surface. An air gap of about $2.6 \mathrm{~cm}$ exists between the film and the surface of distilled water inside the cup. The temperature set condition was $16{ }^{\circ} \mathrm{C}$ and a thermo-hygrometer (HANNA Instruments) was introduced in the test chamber to record relative humidity (RH). The RH value inside the cups (100\%) was higher than the RH outside the cups (1.8-11.3\%). The weight loss of the cups was monitored over a $24 \mathrm{~h}$ period with intervals of at least $3 \mathrm{~h}$ between readings. The water vapour transmission rate was calculated by linear regression of the plotted weight loss slope as function of time and dividing by the exposed area of the films $\left(8.04 \times 10^{-4} \mathrm{~m}^{2}\right)$. Permeance was calculated according to Gennadios, Weller, and Gooding (1994), taking in consideration the air gap resistance due to stagnant air layer between the underside of the film and the surface of distilled water contained in the cup. Water vapour permeability was calculated as the product of permeance and the average thickness of the film. All tests were done in triplicate.

\subsection{Mechanical properties of films}

Puncture strength of the films was measured on a texturometer TA-XT2 (Stable Micro System, UK) by mounting squared film strips $30 \mathrm{~mm} \times 30 \mathrm{~mm}$ on a specially designed base with a hole of $9.89 \mathrm{~mm}$ diameter. With a cylindrical probe of $2 \mathrm{~mm}$ and a test speed of $2.0 \mathrm{~mm} / \mathrm{s}$ in a compression mode, the films were punctured through the hole and the distance $(\mathrm{mm})$ travelled by the probe and the force $(\mathrm{N})$ at the point of rupture was recorded, divided by probe area and expressed as puncture stress (PS). The percentage of elongation (\%E) at puncture was also calculated. At least 15 measurements were done. All mechanical tests were performed at $50 \pm 5 \%$ relative humidity and a temperature of $23 \pm 2{ }^{\circ} \mathrm{C}$.

\subsection{Rheological measurements}

The rheological measurements were performed in a controlledstress rheometer (RS75; HAAKE, Germany), at $20 \pm 0.1^{\circ} \mathrm{C}$, using serrated parallel plate geometry (PP60), in order to overcome the slip effect, and a gap of $1.000 \mathrm{~mm}$. Oscillatory tests (mechanical spectra) were carried out using a frequency range of $0.01-100 \mathrm{~Hz}$ and a stress values comprised in the linear viscoelastic region for each solution (1-2 Pa). Steady-state flow measurements were also done and viscosity versus shear stress curves were performed using a logarithmic ramp of stresses increasing in 17-30 min from $0.001 \mathrm{~Pa}$ to $2300 \mathrm{~Pa}$. In all cases, at least two measurements were done. The rhelogical measurements were done on the film solutions based on whey protein isolate $(7 \% \mathrm{w} / \mathrm{v})$, malic acid $(3 \% \mathrm{w} /$ $\mathrm{v})$, glycerol $(3 \% \mathrm{w} / \mathrm{v})$, with the incorporation of nisin $(50 \mathrm{IU} / \mathrm{ml})$ and/or natamycin $(0.005 \mathrm{~g} / \mathrm{ml})$, with the purpose to study the influence of natamycin in viscosity and viscoelastic properties of the solutions.

\subsection{Statistical analysis}

Statistic for data analysis was done with version 14.0 and 16.0 of the SPSS program (SPSS Inc., Chicago, USA). Scheffé's multiple range test $(P<0.05)$ was used to detect differences in film properties mean values.

\section{Results and discussion}

\subsection{Antimicrobial activity}

Our previous work (Pintado, Sousa, \& Ferreira, 2006) revealed that WPI $(7.0 \% \mathrm{w} / \mathrm{v})$-based films with glycerol $(3.0 \% \mathrm{w} / \mathrm{v})$ as plasticizer, malic acid $(3.0 \% \mathrm{w} / \mathrm{v})$ as antimicrobial and acidifying agent, and nisin $(50 \mathrm{IU} / \mathrm{ml})$ as antimicrobial agent are effective to control foodborne pathogenic $L$. monocytogenes strains isolated from cheese samples when tested in a disc-diffusion assay. Since the rind of cheeses have a wide range of other microorganisms, including bacteria, moulds and yeasts, and since nisin is an antimicrobial agent with efficacy only for Gram-positive bacteria, the introduction of the antimycotic agent natamycin in the whey protein isolate-glycerol-malic acid (WPI-G-MA) films was analysed. The results (Table 2) revealed that $Y$. lipolytica and Penicillium spp. strains were only inhibited by the incorporation of natamycin into the films, as we expected, and the zones of inhibition were independent of the acid used to lower the $\mathrm{pH}$ of the films to approximately 3 . A higher inhibitory effect against $L$. monocytogenes was observed with malic acid in association with nisin. No inhibitory 
Table 2

Zones of inhibition ( $\mathrm{mm}$ ) produced by low $\mathrm{pH}$ (3) antimicrobial films made with whey protein isolate, WPI (7.0\% w/v), glycerol, G (3.0\% w/v), acids (3.0\% w/v) and a combination of different agents (nisin, $50 \mathrm{IU} / \mathrm{ml}$, and natamycin, $0.005 \mathrm{~g} / \mathrm{ml}$ ), in an antimicrobial disc-diffusion assay using TSYEGA or GYPA medium at pH 6.2.

\begin{tabular}{|c|c|c|c|c|}
\hline \multirow[t]{2}{*}{ Composition of WPI-G films } & \multicolumn{4}{|c|}{ Zones of inhibition (mm) } \\
\hline & $\begin{array}{l}\text { L. monocytogenes } \\
\text { CP6 }\end{array}$ & $\begin{array}{l}\text { Ps. aeruginosa } \\
\text { P6 }\end{array}$ & $\begin{array}{l}\text { Y. lipolytica } \\
\text { ISA1708 }\end{array}$ & $\begin{array}{l}\text { P. roqueforti } \\
\text { PRB6 HYP5D }\end{array}$ \\
\hline Malic acid & 2.5 & 0.5 & $(-)$ & $(-)$ \\
\hline Malic acid + Natamycin & 1.2 & 0.5 & 8.3 & 12.4 \\
\hline Malic acid + Nisin & 3.2 & 0.8 & $(-)$ & $(-)$ \\
\hline Malic acid + Natamycin + Nisin & 3.3 & 1.0 & 8.4 & 12.4 \\
\hline $\mathrm{HCl} 2 \mathrm{~N}$ & $(-)$ & 0 & $(-)$ & $(-)$ \\
\hline $\mathrm{HCl} 2 \mathrm{~N}+$ Natamycin & $(-)$ & 0 & 8.0 & 11.9 \\
\hline $\mathrm{HCl} 2 \mathrm{~N}+\mathrm{Nisin}$ & 0.6 & 0 & $(-)$ & $(-)$ \\
\hline $\mathrm{HCl} 2 \mathrm{~N}+$ Natamycin + Nisin & 0.6 & 0 & 8.0 & 11.6 \\
\hline
\end{tabular}

(-) No inhibition under or around the film; 0 - growth inhibition just under the film.

effect around the disc films was observed against Ps. aeruginosa strain when nisin with $\mathrm{HCl} 2 \mathrm{~N}$ incorporated into WPI films were used. As Ps. aeruginosa is a Gram-negative bacterium, it is nisinresistant because their outer membrane prevents the passage into the cell of large hydrophobic molecules such as nisin (Thomas et al., 1998). The results in Table 2 also showed that no differences existed in the zones of inhibition obtained with nisin alone or nisin plus natamycin against bacteria strains tested, and no differences existed in the zones of inhibition obtained with natamycin alone or natamycin plus nisin against moulds and yeasts strains tested. This suggests an independent action and differentiated targets of nisin and natamycin. Welscher et al. (2008) revealed that natamycin blocks fungal growth by binding specifically to ergosterol, present almost exclusively in the fungi plasma membranes, and not present in bacteria.

A selective antimicrobial activity was seen on the addition of sucrose esters SP30, SP50 and S970 to the whey protein isolatemalic acid-nisin-natamycin (WPI-MA-N-NA) films (Fig. 1). While the inhibitory effect was slightly improved for L. monocytogenes strains or was nonexistent for the Ps. aeruginosa strains, in the case of yeast and mould strains a considerable decrease in the inhibi-

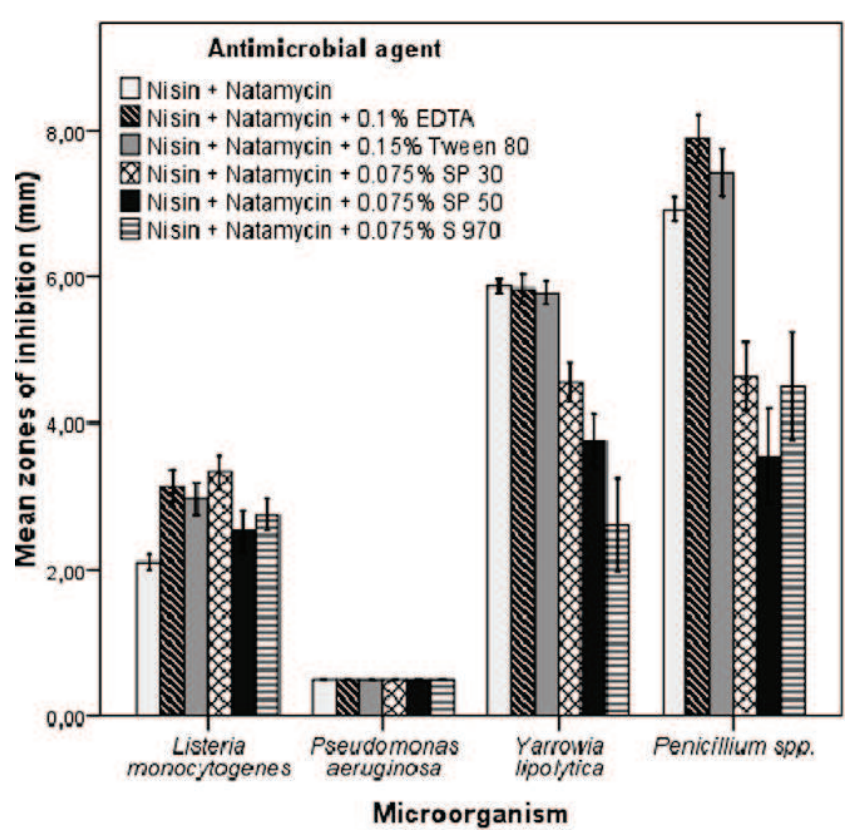

Fig. 1. Effect of the addition of $0.1 \%$ of EDTA, $0.15 \%$ of Tween 80 , and $0.075 \%$ of sucrose esters (SP30, SP50, S970) on antimicrobial activity of films prepared with whey protein isolate $(7 \%)$, nisin $(50 \mathrm{IU} / \mathrm{ml})$, natamycin $(0.002 \mathrm{~g} / \mathrm{ml})$ and sorbitol or glycerol $(1.5 \%, 2.25 \%, 3.0 \%)$ as plasticizer, against strains of $L$. monocytogenes, Ps. aeruginosa, Y. lipolytica and Penicillium spp. Error bars represent \pm 1 standard error. tory effect was observed when the sucrose esters were added. These results suggested an antagonistic interaction between sucrose esters and the other film components for the fungi growth control. A probable explanation is based on the capacity of sucrose esters to bind with ergosterol, diminishing the target site of natamycin. Despite the decrease of natamycin activity observed, the antifungal action was not completely lost. An antimicrobial effect of sucrose fatty acid esters, alone or in association with nisin, against L. monocytogenes has been reported previously (Monk \& Beuchat, 1995; Thomas et al., 1998). This work showed that this effect was not negligible when these agents were incorporated into a whey protein based film, with respect to L. monocytogenes.

All five agents studied improved the inhibitory activity of nisin and malic acid against $L$. monocytogenes. In opposition, none of these five agents enhanced the natamycin activity against $Y$. lipolytica and Ps. aeruginosa strains. Boziaris and Adams (1999) reported a poor chelating power of EDTA under acidic conditions, however a small enhanced inhibitory effect when EDTA and nisin were used against $L$. monocytogenes and Penicillium spp. strains was observed. This was also reported by Branen and Davidson (2003), with respect to $L$. monocytogenes. Treatment with metal-chelating agents as EDTA generally results in removal of divalent cations by chelation the lipopolysaccharide (LPS) layer of the outer membrane of Gram-negative bacteria, destabilizing its structure, thus increasing permeability (Vaara, 1992), and promoting the activity of other antimicrobials. There is a considerable variability of EDTA sensitivity for various species of the genera Pseudomonas and Ps. aeruginosa is considered to be EDTA-sensitive (Ayres, Furr, \& Russel, 1999). Maybe the three strains of Ps. aeruginosa studied here have resistance mechanisms or the EDTA concentration was too low to produce any effect.

The effect of the agents tested on inhibition of Ps. aeruginosa strains in TSYGA medium showed that none was able to cause an increase of inhibition. Thomas et al. (1998) also reported no antimicrobial effect against Gram-negative bacteria when nisin was used alone or in combination with sucrose esters of fatty acids. In food protection, Gram-negative bacteria are of great concern due to their inherent resistance to some antimicrobials because of the protective action of the outer membrane of the cell wall (Belfiore, Castellano, \& Vignolo, 2007).

Tween $80(0.15 \%, w / v)$ did not enhance the inhibitory activity of nisin and natamycin against Ps. aeruginosa and Y. lipolytica but the antimicrobial effect was improved with the addition of Tween 80 against L. monocytogenes and Penicillium spp.

\subsection{Viscosity and viscoelastic properties}

Under SAOS, the mechanical spectra of the film solutions based on whey protein isolate $(7 \% \mathrm{w} / \mathrm{v})$, malic acid $(3 \% \mathrm{w} / \mathrm{v})$, glycerol $(3 \% \mathrm{w} / \mathrm{v})$ and nisin $(50 \mathrm{IU} / \mathrm{ml})$ exhibited a predominantly viscous 


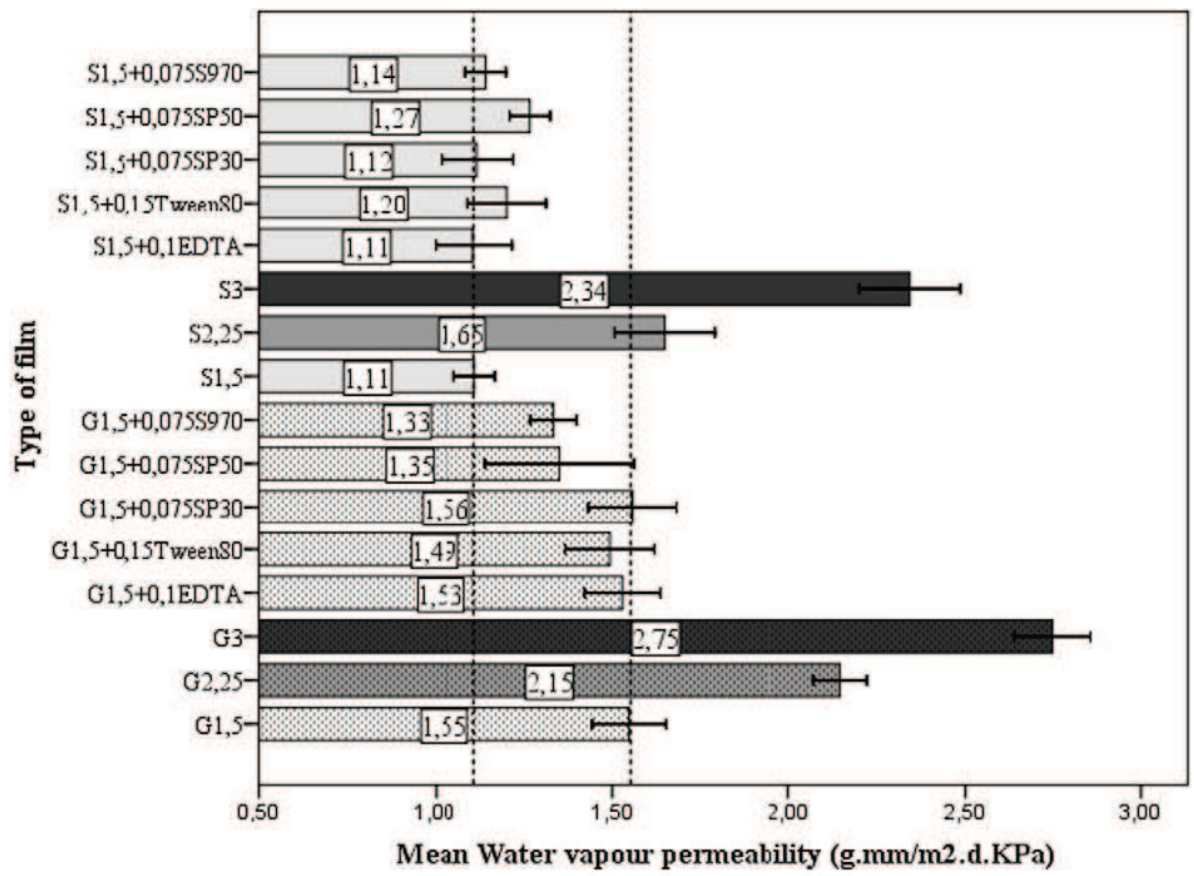

Fig. 2. Mean values of water vapour permeability ( $\mathrm{g} \mathrm{mm} / \mathrm{m}^{2} \mathrm{~d} \mathrm{kPa}$ ) for films produced with sorbitol (S) or glycerol (G) as plasticisers (at $1.5 \%$, $2.25 \%$ and $3.0 \%$ ), alone or with sucrose esters (SP30, SP50 and S970, all at $0.075 \%, \mathrm{w} / \mathrm{v})$, EDTA $(0.1 \%, \mathrm{w} / \mathrm{v})$ or Tween $80(0.15 \%, \mathrm{w} / \mathrm{v})$. All films are based on whey protein isolate $(7.0 \%, \mathrm{w} / \mathrm{v})$, malic acid (3.0\%, w/ $\mathrm{v})$, nisin $(50 \mathrm{IU} / \mathrm{ml})$ and natamycin $(0.002 \mathrm{~g} / \mathrm{ml})$. Error bars represent \pm 1 standard error.

behaviour, where the loss modulus was greater than the storage modulus (around 0.45 and 0.25 , respectively). This behaviour was not modified by natamycin $(0.005 \mathrm{~g} / \mathrm{ml})$ incorporation. Under steady shear, the limiting viscosity $\eta_{0}$ of first Newtonian plateau for the solutions tested showed to be unaffected by the addition of natamycin compared to solutions based on whey protein isolate, malic acid, glycerol and nisin, both with a shear thinning pattern and a first limiting viscosity $\eta_{0}$ value closer to $10^{-1} \mathrm{~Pa}$ s. This fluid showed a low apparent viscosity, which is favourable to its industrial use in curtain or applications dip coating.

\subsection{Water vapour permeability}

The results show that an increase of concentration of glycerol and sorbitol from $1.5 \%$ to $3.0 \%$ resulted in an increase in WVP (from
1.55 to $2.75 \mathrm{~g} \mathrm{~mm} / \mathrm{m}^{2} \mathrm{~d} \mathrm{kPa}$ for glycerol and from 1.11 to $2.34 \mathrm{~g} \mathrm{~mm} / \mathrm{m}^{2} \mathrm{~d} \mathrm{kPa}$ for sorbitol) (Fig. 2). Several authors had observed this behaviour (Irissin-Mangata, Bauduin, Boutevin, \& Gontard, 2001; Maté \& Krochta, 1996; Vanin, Sobral, Menegalli, Carvalho, \& Habitante, 2005), which is usual in hygroscopic films, such as WPI protein films. Hydroxyl groups of the plasticizers replace polymer-polymer interactions by developing polymer-plasticizer hydrogen bonds, thereby increasing intermolecular spacing and permeability of film material (McHugh, Aujard, \& Krochta, 1994). The increase of plasticizer concentration resulted in a linear relation between the amount of plasticizer and WVP. Maté and Krochta (1996) reported the same effect when WPI films plasticized with glycerol were studied.

At equal concentrations, sorbitol (S)-plasticized whey protein films, exhibited significantly $(P<0.05)$ lower WVP than films with

Table 3

Measured mechanical properties (puncture stress and\% of elongation) for composite films based on whey protein isolate, WPI (7.0\% w/v), malic acid, MA (3.0\% w/v), nisin, $\mathrm{N}$ $(50 \mathrm{IU} / \mathrm{ml})$ and natamycin, NA $(0.002 \mathrm{~g} / \mathrm{ml})$, prepared with different agents (EDTA, Tween80, and sucrose esters: SP30, SP50 and S970) and glycerol or sorbitol at different concentrations.

\begin{tabular}{|c|c|c|c|c|}
\hline \multirow[t]{2}{*}{ Agents incorporated in WPI-MA-N-NA films } & \multicolumn{2}{|c|}{ Puncture stress (MPa) } & \multicolumn{2}{|l|}{ \% Elongation } \\
\hline & Mean \pm SD & SE & Mean \pm SD & SE \\
\hline 1.5\% Glycerol & $0.690 \pm 0.122 b c$ & 0.030 & $4.10 \pm 0.35 \mathrm{ab}$ & 0.09 \\
\hline 2.25\% Glycerol & $0.692 \pm 0.160 b c$ & 0.036 & $5.99 \pm 1.06 \mathrm{e}$ & 0.24 \\
\hline 3.0\% Glycerol & $0.391 \pm 0.465 \mathrm{a}$ & 0.010 & $5.46 \pm 0.92$ cde & 0.21 \\
\hline $1.5 \%$ Glycerol + 0.1\% EDTA & $0.895 \pm 0.271 \mathrm{~cd}$ & 0.078 & $4.26 \pm 0.37 \mathrm{abc}$ & 1.11 \\
\hline $1.5 \%$ Glycerol + 0.15\% Tween 80 & $1.010 \pm 0.175 \mathrm{defg}$ & 0.039 & $5.64 \pm 0.66 \mathrm{de}$ & 0.15 \\
\hline 1.5\% Glycerol + 0.075\% SP30 & $0.906 \pm 0.116 \mathrm{cde}$ & 0.025 & $5.16 \pm 0.66 \mathrm{bcde}$ & 0.15 \\
\hline $1.5 \%$ Glycerol + $0.075 \%$ SP50 & $0.983 \pm 0.121 \mathrm{def}$ & 0.027 & $5.02 \pm 0.38$ bcde & 0.08 \\
\hline $1.5 \%$ Glycerol + 0.075\% S970 & $1.108 \pm 0.143 \mathrm{defg}$ & 0.045 & $5.05 \pm 0.37 \mathrm{bcde}$ & 0.12 \\
\hline $1.5 \%$ Sorbitol & $0.910 \pm 0.066 \mathrm{cde}$ & 0.015 & $4.43 \pm 0.61 \mathrm{abcd}$ & 0.14 \\
\hline $2.25 \%$ Sorbitol & $1.051 \pm 0.058 \mathrm{defg}$ & 0.018 & $4.36 \pm 0.55 \mathrm{abc}$ & 0.18 \\
\hline 3.0\% Sorbitol & $0.593 \pm 0.089 a b$ & 0.019 & $3.67 \pm 0.47 a$ & 0.10 \\
\hline $1.5 \%$ Sorbitol + $0.1 \%$ EDTA & $1.178 \pm 0.224 \mathrm{efg}$ & 0.051 & $4.25 \pm 1.30 \mathrm{abc}$ & 0.30 \\
\hline $1.5 \%$ Sorbitol $+0.15 \%$ Tween 80 & $1.232 \pm 0.229 \mathrm{fg}$ & 0.052 & $4.68 \pm 0.55 \mathrm{abcd}$ & 0.13 \\
\hline $1.5 \%$ Sorbitol + $0.075 \%$ SP30 & $1.081 \pm 0.142 \mathrm{defg}$ & 0.032 & $4.22 \pm 0.59 \mathrm{abc}$ & 0.13 \\
\hline $1.5 \%$ Sorbitol $+0.075 \%$ SP50 & $1.275 \pm 0.197 \mathrm{~g}$ & 0.045 & $4.30 \pm 1.04 \mathrm{abc}$ & 0.24 \\
\hline $1.5 \%$ Sorbitol $+0.075 \%$ S970 & $0.960 \pm 0.188 \mathrm{cdef}$ & 0.046 & $3.71 \pm 0.28 \mathrm{a}$ & 0.07 \\
\hline
\end{tabular}

SD, standard deviation; SE, standard error. Means $(n \geqslant 15)$ bearing different superscripts are significantly different $(P<0.05$, Scheffé test). 
glycerol (G), maybe due to the fact that glycerol is more polar, more soluble and is a smaller molecule than sorbitol. Kim and Ustunol (2001) reported that glycerol is more hygroscopic than sorbitol.

The water vapour permeability was not affected by the incorporation of sucrose esters (S970, SP30 or SP50), EDTA or Tween80 on WPI-plasticized (1.5\%) films (Fig. 2).

\subsection{Mechanical properties}

In general, glycerol-WPI films had higher\% elongation (\%E) and lower puncture stress (PS) than sorbitol-WPI films. Higher values of \%E for glycerol-WPI films are probably attributed to the fact that these films contain more plasticizer per mol than those containing sorbitol, since the molecular weight of sorbitol is twice than that of glycerol (182 and 92 of Mw, respectively). Several authors had observed a molecular weight effect of the plasticizer on the mechanical properties (Sothornvit \& Krochta, 2001; Sothornvit, Olsen, McHugh, \& Krochta, 2007). On the other hand, the glycerol molecules possess a very high dielectric constant, a higher polarity in solution and are more hygroscopic than sorbitol.

Sucrose esters, EDTA or Tween80 increased significantly $(P<0.05)$ the PS and the \%E of WPI-glycerol $(1.5 \%)$ films (Table 3 ). Regarding WPI-sorbitol (1.5\%) films, the addition of sucrose esters, EDTA or Tween 80 increased the PS but had no significant effect on \%E.

Glycerol (3.0\%)-WPI films showed significantly $(P<0.05)$ lower puncture stress than the other formulations. Values of PS showed the most consistent dependence on plasticizer content while \% $\mathrm{E}$ relationship to plasticizer content was somewhat variable.

\section{Conclusions}

This work demonstrated the positive effect of nisin, malic acid and natamycin-impregnated whey protein films against L. monocytogenes, Ps. aeruginosa, $Y$. lipolytica and $P$. commune and $P$. chrysogenum. The ability of the studied films to be a carrier of antimicrobials without significantly compromising the mechanical properties of films was demonstrated. Concerning the water vapour permeability, the films with glycerol at $3.0 \%$ showed the higher values and the films with sorbitol at $1.5 \%$ had the lower values. The overall results of antimicrobial assay, mechanical and WVP tests allow us to suggest the following formulation to be later evaluated in an experimental assay to wrap cheese: whey protein isolate (7.0\%), malic acid (3.0\%), sorbitol (1.5\%), nisin (50 IU $/ \mathrm{ml})$, natamycin $(0.002 \mathrm{~g} / \mathrm{ml})$. EDTA can also be used, since it increased the inhibitory power against $L$. monocytogenes, $P$. commune and $P$. chrysogenum. A concentration higher than $0.1 \%$ needs to be investigated to demonstrate inhibition against Ps. aeruginosa.

\section{Acknowledgements}

This work was supported by the Portuguese Foundation for Science and Technology (Project PTDC/AGR-ALI/67194/2006). Cristina Pintado was funded by a PhD scholarship from the Programa de Desenvolvimento Educativo para Portugal (2/5.3/PRODEP/2003). The authors thank Vítor Alves (Faculdade de Ciências e Tecnologia, Universidade Nova de Lisboa) and Helena Oliveira (Instituto Superior de Agronomia, Technical University of Lisbon) for technical advice in water vapour permeability assays and moulds identification, respectively.

\section{References}

Appendini, P., \& Hotchkiss, J. H. (2002). Review of antimicrobial food packaging. Innovative Food Science \&' Emerging Technologies, 3, 113-126.
ASTM (1995). Standard test methods for water vapour transmission of materials. E 96-95. In: Annual book of ASTM standards. Philadelphia, PA: American Society for Testing and Materials.

Ayres, H. M., Furr, J. R., \& Russel, A. D. (1999). Effect of permeabilizers on antibiotic sensitivity of Pseudomonas aeruginosa. Letters in Applied Microbiology, 28, 13-16.

Belfiore, C., Castellano, P., \& Vignolo, G. (2007). Reduction of Escherichia coli population following treatment with bacteriocins from lactic acid bacteria and chelators. Food Microbiology, 24, 223-229.

Boziaris, I., \& Adams, M. (1999). Effect of chelators and nisin produced in situ on inhibition and inactivation of Gram negatives. International Journal of Food Microbiology, 53, 105-113.

Branen, J., \& Davidson, P. (2003). Enhancement of nisin, lysozyme and monolaurin antimicrobial activities by ethylenediaminetetraacetic acid and lactoferrin. International Journal of Food Microbiology, 90, 63-74.

Carreira, A., Paloma, A., \& Loureiro, V. (1998). Pigment producing yeasts involved in a brown surface discoloration of eweścheese. International Journal of Food Microbiology, 41, 223-230.

Delves-Broughton, J. (2005). Nisin as a food preservative. Food Australia, 57(12), 525-527.

EFSA (2005). Opinion of the scientific panel on food additives, flavourings, processing aids and materials in contact with food, on a request from the commission related to the use of polyvinyl alcohol as a coating agent for food supplements (question number EFSA-Q-2005-017). The EFSA Journal, 294, 1-15.

Gennadios, A., Weller, C. L., \& Gooding, C. H. (1994). Measurement errors in water vapour permeability of highly permeable, hydrophilic edible films. Journal of Food Engineering, 21, 395-409.

Irissin-Mangata, J., Bauduin, G., Boutevin, B., \& Gontard, N. (2001). New plasticizers for wheat gluten films. European Polymer Journal, 37, 1533-1541.

Kim, S.-J., \& Ustunol, Z. (2001). Solubility and moisture sorption isotherms of wheyprotein-based edible films as influenced by lipid and plasticizer incorporation. Journal of Agricultural and Food Chemistry, 49, 4388-4391.

Ko, S., Janes, M. E., Hettiarachchy, N. S., \& Johnson, M. G. (2001). Physical and chemical properties of edible films containing nisin and their action against Listeria monocytogenes. Journal of Food Science, 66(7), 1006-1011.

Maté, J. I., \& Krochta, J. M. (1996). Comparison of oxygen and water vapor permeabilities of whey protein isolate and $\beta$-lactoglobulin edible films. Journal of Agricultural and Food Chemistry, 44, 3001-3004.

McHugh, T. H., Aujard, J.-F., \& Krochta, J. M. (1994). Plasticized whey protein edible films: Water vapor permeability properties. Journal of Food Science, 59(2), 416-419.

McHugh, T. H., Avena-Bustillos, R., \& Krochta, J. M. (1993). Hydrophilic edible films: Modified procedure for water vapour permeability and explanation of thickness effect. Journal of Food Science, 58, 899-903.

McLauchlin, J. Mitchell, R. T., Smerdon, W. J, \& Jewell, K. (2004). Listeria monocytogenes and listeriosis: A review of hazard characterisation for use in microbiological risk assessment of foods. International Journal of Food Microbiology, 92, 15-33.

Monk, J. D., \& Beuchat, L. R. (1995). Viability of Listeria monocytogenes, Staphylococcus aureus and psychotrophic spoilage micro-organisms in refrigerated ground beef supplemented with sucrose esters of fatty acids. Food Microbiology, 12, 397-404.

Monk, J. D., Beuchat, L. R., \& Hathcox, A. K. (1996). Inhibitory effects of sucrose monolaurate, alone or in combination with organic acids, on Listeria monocytogenes and Staphylococcus aureus. Journal of Applied Bacteriology, 81, $7-18$.

Ogunnariwo, J., \& Hamilton-Miller, J. M. (1975). Brown- and red-pigmented Pseudomonas aeruginosa. Differentiation between melanin and pyrubrin. Journal of Medical Microbiology, 8, 199-203.

Pintado, C. M. B. S., Oliveira, A., Pampulha, M. E., \& Ferreira, M. A. S. S. (2005). Prevalence and characterization of Listeria monocytogenes isolated from soft cheeses. Food Microbiology, 22, 79-85.

Pintado, C. M. B. S., Sousa, I., \& Ferreira, M. A. A. S. (2006). Edible films with bioactive characteristics against Listeria monocytogenes. In: Book of proceedings of the 2006 EFFoST Annual Meeting/Total Food 2006 - Sustainability of the Agri-Food Chain, The Hague, The Netherlands.

Samson, R. A., Frisvad, J. C. (2005). Penicillium subgenus Penicillium: New taxonomic schemes and mycotoxins and other extrolites. Issue 49: Penicillium subgenus Penicillium. Studies in Mycology. Centraalbureau voor Schimmelcultures, The Netherlands. http://www.studiesinmycology.org/en/ content/49/toon Accessed October 2006.

Sorhaug, T., \& Stepaniak, L. (1997). Psychrotrophs and their enzymes in milk and dairy products: Quality aspects. Trends in Food Science E Technology, 8, 35-41.

Sothornvit, R., \& Krochta, J. M. (2001). Plasticizer effect on mechanical properties of $\beta$-lactoglobulin films. Journal of Food Engineering, 50, 149-155.

Sothornvit, R., Olsen, C. W., McHugh, T. H., \& Krochta, J. M. (2007). Tensile properties of compression-molded whey protein sheets: Determination of molding condition and glycerol-content effects and comparison with solution-cast films. Journal of Food Engineering, 78, 855-860.

Stevens, K. A., Sheldon, B. W., Klapes, N. A., \& Klaenhammer, T. R. (1992). Effect of treatment conditions on nisin inactivation of Gram-negative bacteria. Journal of Food Protection, 55(10), 763-766.

Thomas, L. V., Davies, E. A., Delves-Broughton, J., \& Wimpenny, J. W. T. (1998). Synergist effect of sucrose fatty acid esters on nisin inhibition of Gram-positive bacteria. Journal of Applied Microbiology, 85, 1013-1022.

Vaara, M. (1992). Agents that increase the permeability of the outer membrane. Microbiological Reviews, 56(3), 395-411. 
Vanin, F. M., Sobral, P. J. A., Menegalli, F. C., Carvalho, R. A., \& Habitante, A. M. Q. B.

(2005). Effects of plasticizers and their concentrations on thermal and functional properties of gelatin-based films. Food Hydrocolloids, 19, 899-907.
Welscher, Y. M., Napel, H. H., Balagué, M. M., Souza, C. M., Riezman, H., Kruijff, B., et al. (2008). Natamycin blocks fungal growth by binding specifically to ergosterol without permeabilizing the membrane. Journal of Biological Chemistry, 283(10), 6393-6401. 